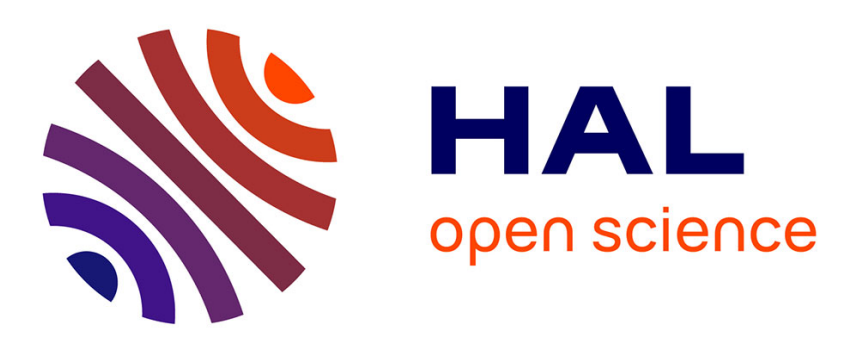

\title{
A new homodimer of aciclovir as a prodrug with increased solubility and antiviral activity
}

Giorgio Brandi, Luigia Rossi, Giuditta F. Schiavano, Enrico Millo, Mauro

Magnani

\section{- To cite this version:}

Giorgio Brandi, Luigia Rossi, Giuditta F. Schiavano, Enrico Millo, Mauro Magnani. A new homodimer of aciclovir as a prodrug with increased solubility and antiviral activity. International Journal of Antimicrobial Agents, 2009, 34 (2), pp.177. 10.1016/j.ijantimicag.2009.02.025 . hal-00556335

\section{HAL Id: hal-00556335 https://hal.science/hal-00556335}

Submitted on 16 Jan 2011

HAL is a multi-disciplinary open access archive for the deposit and dissemination of scientific research documents, whether they are published or not. The documents may come from teaching and research institutions in France or abroad, or from public or private research centers.
L'archive ouverte pluridisciplinaire HAL, est destinée au dépôt et à la diffusion de documents scientifiques de niveau recherche, publiés ou non, émanant des établissements d'enseignement et de recherche français ou étrangers, des laboratoires publics ou privés. 


\section{Accepted Manuscript}

Title: A new homodimer of aciclovir as a prodrug with

increased solubility and antiviral activity

Authors: Giorgio Brandi, Luigia Rossi, Giuditta F. Schiavano, Enrico Millo, Mauro Magnani

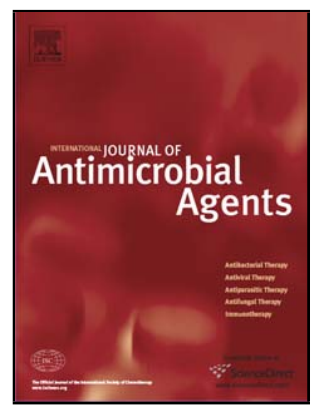

PII:

S0924-8579(09)00133-2

DOI: doi:10.1016/j.ijantimicag.2009.02.025

Reference: ANTAGE 3013

To appear in:

International Journal of Antimicrobial

Agents

Received date: $\quad 16-1-2009$

Revised date: $\quad 19-2-2009$

Accepted date: $\quad$ 19-2-2009

Please cite this article as: Brandi G, Rossi L, Schiavano GF, Millo E, Magnani M, A new homodimer of aciclovir as a prodrug with increased solubility and antiviral activity, International Journal of Antimicrobial Agents (2008), doi:10.1016/j.ijantimicag.2009.02.025

This is a PDF file of an unedited manuscript that has been accepted for publication. As a service to our customers we are providing this early version of the manuscript. The manuscript will undergo copyediting, typesetting, and review of the resulting proof before it is published in its final form. Please note that during the production process errors may be discovered which could affect the content, and all legal disclaimers that apply to the journal pertain. 


\section{A new homodimer of aciclovir as a prodrug with increased solubility and antiviral activity}

Giorgio Brandi $^{\mathrm{a}, \star}$, Luigia Rossi ${ }^{\mathrm{b}}$, Giuditta F. Schiavano ${ }^{a}$, Enrico Millo ${ }^{\mathrm{c}}$, Mauro Magnani ${ }^{b}$

a Department of Biomolecular Sciences, Hygiene Section, University of Urbino 'Carlo Bo', Via S. Chiara 27, 61029 Urbino (PU), Italy

${ }^{\mathrm{b}}$ Department of Biomolecular Sciences, Biochemistry and Molecular Biology Section, University of Urbino 'Carlo Bo', Via Saffi 2, 61029 Urbino (PU), Italy

${ }^{\mathrm{c}}$ Department of Experimental Medicine, Biochemistry Section and Center of Excellence for Biomedical Research, University of Genoa, Viale Benedetto XV 1, 16132 Genoa, Italy

Received 16 January 2009; accepted 19 February 2009

Keywords: Antiviral prodrug; Aciclovir homodimer; Anti-HSV-1 activity

* Corresponding author. Tel.: +39 072230 3542; fax:+39 0722303541.

E-mail address: giorgio.brandi@uniurb.it (G. Brandi). 


\section{Abstract}

Aciclovir (ACV) is the drug of choice against herpes simplex virus type 1 (HSV-1) infection. However, its limited solubility in water and limited oral bioavailability represent the main limitations of this drug. Utilising a plaque reduction assay, this study assessed the antiherpetic activity of a new homodimer of $A C V\left(A C V p_{2} A C V\right)$ with a higher water solubility. ACVp ${ }_{2} \mathrm{ACV}$ markedly inhibited HSV-1 replication in Vero cells [50\% effective concentration $\left(\mathrm{EC}_{50}\right)$ of $2.8 \mu \mathrm{M}$ vs. $6.6 \mu \mathrm{M}$ for $\left.\mathrm{ACV}\right]$ and was non-toxic in the cells at concentrations $\leq 15 \mu \mathrm{M} . \mathrm{ACV} \mathrm{p}_{2} \mathrm{ACV}$ encapsulated in erythrocytes provides effective protection against HSV-1 replication in human macrophages and also partially against the HSV-1 thymidine kinase-deficient strain. Thus, $A C V p_{2} A C V$ acts as an effective antiviral prodrug against HSV-1. 


\section{Introduction}

Herpes simplex virus (HSV) infections represent a global health problem occurring worldwide in ca. $80 \%$ of the population [1]. Although the primary disease is seen in less than one-half of the population and infections are often subclinical, one-third of infected subjects suffer from recurrent HSV infection several times a year. HSV mainly attacks the skin or mucous membranes, however it can also cause rare, but serious, diseases including encephalitis, blindness and neonatal infections [2]. Furthermore, HSV can cause severe disease in immunocompromised patients, for example in patients with acquired immunodeficiency syndrome (AIDS), where it represents the most frequent causes of viral infection [3].

The nucleoside analogue aciclovir (ACV) is the antiviral drug of choice for the treatment of HSV infections both in immunocompetent and immunosuppressed patients owing to its efficacy and lack of toxicity $[1,4]$. The drug acts only in HSVinfected cells, where it is first converted to aciclovir monophosphate (ACV-MP) by viral-encoded thymidine kinase (TK) and further converted sequentially into the diphosphorylated and triphosphorylated forms by cellular enzymes. Aciclovir triphosphate (ACV-TP) is incorporated into viral DNA chains and acts as a chain terminator [5]. The polymerase is also functionally inactivated, becoming irreversibly bound to the terminated DNA chain. However, like other antiherpetic agents currently used in HSV infections, ACV fails to eliminate the virus from the body and to prevent re-infection/reactivation, mainly because although it reduces the production of new viral particles it cannot counteract early HSV infection or prevent the emergence of resistant viral strains. For these reasons, in the search for an improved antiviral 
treatment, we investigated the antiherpetic activity of a novel homodimer of ACV, $\mathrm{ACV} \mathrm{p}_{2} \mathrm{ACV}$.

\section{Material and methods}

\subsection{Synthesis of acycloguanosine homodinucleotide $\left(A C V p_{2} A C V\right)$}

Phosphorus oxychloride was slowly added to a cooled, stirred suspension of acycloguanosine $(1 \mathrm{mmol})$ in triethyl phosphate $(15 \mathrm{~mL})$. After $3 \mathrm{~h}$ at $0{ }^{\circ} \mathrm{C}$, acycloguanosine monophosphate was poured into ether and the precipitate was separated. The product was dissolved in deionised water and immediately neutralised with $1 \mathrm{~N} \mathrm{NaOH}$. The solution was evaporated to dryness under vacuum, yielding $95-100 \%$ acycloguanosine monophosphate, which was converted into the acidic form with Dowex $50 \mathrm{~W} \mathrm{H}+$ form.

A solution of dicyclohexylcarbodiimide $(4 \mathrm{mmol})$ in $t$-butyl alcohol $(15 \mathrm{~mL})$ was added drop-wise to a refluxing solution of acycloguanosine monophosphate $(1 \mathrm{mmol}$ of free acid) in a mixture of water $(10 \mathrm{~mL}), t$-butyl alcohol $(10 \mathrm{~mL})$ and morpholine $(4 \mathrm{mmol})$. After $3 \mathrm{~h}$ the solution was cooled to room temperature and following addition of few millilitres of deionised water it was washed three times with ether. The aqueous solution was then evaporated to dryness in vacuum, yielding $90 \%$ pure acycloguanosine monophosphate morpholidate.

Acycloguanosine monophosphate morpholidate was dried by three evaporations of its solution in pyridine (solution A). Acycloguanosine monophosphate (1 mmol of free acid) was suspended in methanol, and tri- $n$-butylamine $(2 \mathrm{mmol})$ was added. The 
suspension was stirred to clear the solution and the compound was dried three times by evaporation (solution $B$ ). Solutions $A$ and $B$ were mixed and dried in a vacuum. The final residue was dissolved in dry pyridine $(15 \mathrm{~mL})$ and the clear solution was stirred at room temperature for $96 \mathrm{~h}$. The mixture was evaporated to dryness and dissolved in water. The $\mathrm{pH}$ was adjusted to 8 with $1 \mathrm{~N} \mathrm{NaOH}$ and this solution was then washed with ether. Finally the aqueous solution was evaporated to dryness and after high-performance liquid chromatography (HPLC) purification acycloguanosine homodinucleotide was obtained in $50 \%$ yield. The structure was confirmed by mass spectrometry analysis.

\subsection{Solubility of $A C V p_{2} A C V$}

To evaluate bioavailability, the homodimer was tested for solubility in $\mathrm{H}_{2} \mathrm{O}_{2}$ at $20^{\circ} \mathrm{C}$ and atmospheric pressure. The solubility of free acid was $2 \mathrm{mg} / \mathrm{mL}$ (at $\mathrm{pH} 4)$. The solubility values of the monosodium and bisodium salt of $A C V p_{2} A C V$ were $5 \mathrm{mg} / \mathrm{mL}$ (at $\mathrm{pH} 7.5$ ) and $10 \mathrm{mg} / \mathrm{mL}$ (at $\mathrm{pH} 10)$, respectively. ACV was practically insoluble at $\mathrm{pH} 7.5$.

\section{3. $A C V p_{2} A C V$ stability in plasma}

$\mathrm{ACVp}{ }_{2} \mathrm{ACV}$ was incubated in human plasma $\left(0.08 \mu \mathrm{mol} / \mathrm{mL}\right.$ plasma) for $5 \mathrm{~h}$ at $37^{\circ} \mathrm{C}$; at different incubation times aliquots were removed and perchloric acid extracts were prepared and analysed by HPLC as described by Rossi et al. [6]. 


\section{4. $A C V p_{2} A C V$ metabolism in erythrocyte lysate}

Erythrocyte lysate was obtained as described by Magnani et al. [7]. The haemolysate (105 mg haemoglobin $/ \mathrm{mL}$ ) was incubated at $37^{\circ} \mathrm{C}$ in the presence of $0.1 \mathrm{mM}$ $A C V p_{2} A C V$ in a final volume of $1.2 \mathrm{~mL}$, in the absence or presence of $1 \mathrm{mM} \mathrm{ATP}$. At $0,0.25,0.5,1,2$ and $5 \mathrm{~h}, 250 \mu \mathrm{L}$ aliquots were collected and processed for HPLC determination [6].

\section{5. $A C V p_{2} A C V$ encapsulation in erythrocytes}

Human erythrocytes were loaded with $A C V p_{2} A C V$ and modified to increase their recognition by macrophages using a procedure described by Rossi et al. [6].

\subsection{Cells and viruses}

Vero cells were seeded at a density of $3 \times 10^{5}$ cells/35-mm dish in $2 \mathrm{~mL}$ of Eagle's Minimal Essential Medium (EMEM) supplemented with 10\% heat-inactivated fetal calf serum (FCS) and 1\% antibiotics. Peripheral blood mononuclear cells were obtained from normal healthy blood donors as described previously [8], seeded at a density of $5 \times 10^{5}$ cells/48-well plastic plate in $1 \mathrm{~mL}$ of RPMI- 1640 medium supplemented with 10\% heat-inactivated FCS and $1 \%$ antibiotics and cultured for 10 days, after which the monocytes had matured into macrophages.

The viruses used were a laboratory-adapted strain of HSV-1 (McIntyre) and a thymidine kinase-deficient mutant of $\mathrm{HSV}-1\left(\mathrm{TK}^{-} \Delta 305\right)$. 
For assay of antiviral activity in Vero cells, increasing concentrations of ACV and $\mathrm{ACV} \mathrm{p}_{2} \mathrm{ACV}$ were added $20 \mathrm{~h}$ before infection and continuously throughout the days of culture. Cells were infected for $2 \mathrm{~h}$ with 3 plaque-forming units (PFU)/cell of HSV-1, then repeatedly washed with culture medium and fresh medium was added. The inhibitory effect of the compounds on the replication of HSV-1 was evaluated $48 \mathrm{~h}$ after infection by determining the infectious virus in the supernatants by plaque assay in Vero cells.

For assay of antiviral activity in infected macrophages, unloaded erythrocytes and $A C V p_{2} A C V$-loaded erythrocytes were added $18 \mathrm{~h}$ (overnight) before infection at a ratio of 100 erythrocytes/macrophage. Non-ingested erythrocytes were removed by extensive washing with culture medium. Macrophage cultures were infected for $2 \mathrm{~h}$ with 3 PFU/cell of HSV-1 or $10 \mathrm{PFU} / \mathrm{Cell}$ of $\mathrm{TK}^{-} \Delta 305$, then extensively washed and fresh medium was added. The inhibitory effect of the compounds on the replication of $\mathrm{HSV}-1$ or $\mathrm{TK}^{-} \Delta 305$ was evaluated $48 \mathrm{~h}$ after infection by determining the infectious virus in the supernatants by plaque assay in Vero cells.

For the cytotoxicity assay, Vero cells were seeded as above and treated for $72 \mathrm{~h}$ with increasing concentrations of $\mathrm{ACV}$ and $\mathrm{ACV} \mathrm{p}_{2} \mathrm{ACV}$. Cell monolayers were then rinsed twice with phosphate-buffered saline, trypsinised and counted with a haemocytometer using trypan blue to exclude dead cells. 


\section{Results}

\subsection{Metabolism of $A C V p_{2} A C V$}

To evaluate the metabolism of $\mathrm{ACVp} \mathrm{p}_{2} \mathrm{ACV}$ in human plasma, $0.08 \mu \mathrm{mol}$ of homodimer $/ \mathrm{mL}$ of plasma was incubated for $5 \mathrm{~h}$ at $37^{\circ} \mathrm{C}$. At different incubation times $(0,0.25,0.5,1,2$ and $5 \mathrm{~h})$ the samples were processed for HPLC analysis. As shown in Fig. 1, $A C V p_{2} A C V$ disappeared in a time-dependent manner and was undetectable after $2 \mathrm{~h}$ of incubation, with a concomitant production of ACV-MP that was rapidly dephosphorylated to $A C V$. When $A C V p_{2} A C V(0.1 \mathrm{mM})$ was incubated for $5 \mathrm{~h}$ in erythrocyte lysate, it was converted into ACV-MP that was then rapidly converted into ACV (not shown). However, in presence of 1 mM ATP, a significant reduction (ca. $50 \%$ ) in this conversion was observed.

\subsection{Antiviral activity of $A C V p_{2} A C V$}

The activity of $A C V p_{2} A C V$ was tested in Vero cells, which are highly sensitive to the cytopathic effect of HSV-1. As shown in Fig. 2, both $A C V$ and $A C V p_{2} A C V$ were able to inhibit virus replication in a dose-dependent manner, however the homodimer was much more effective than its parental compound. Specifically, after 2 days of treatment the effective concentration required to reduce the plaque number by $50 \%$ $\left(E_{50}\right)$ was found to be $2.8 \mu \mathrm{M}$ and $6.6 \mu \mathrm{M}$ for $A C V p_{2} A C V$ and $A C V$, respectively. At $15 \mu \mathrm{M}$, the dimer reduced the PFU/mL by >4 log compared with the value of ca. 2 log obtained with ACV.

To evaluate the cytotoxic effects of the drugs, cells were seeded and incubated as reported for the antiviral assay and treated for 3 days with increasing concentrations 
of $\operatorname{ACV}(1,10$ and $30 \mu \mathrm{M})$ or $A C V p_{2} A C V(0.5,5$ and $15 \mu \mathrm{M})$. The results indicated that treatment with either drug did not cause significant toxicity $(<5 \%)$ in Vero cells evaluated both as cell killing and proliferative index, at least at the indicated concentrations (data not shown).

The anti-HSV activity of $A C V p_{2} A C V$ was also tested in human macrophages. In this case, $A C V p_{2} A C V$ was encapsulated in erythrocytes and then targeted to the cells. After incubation overnight with $A C V p_{2} A C V$-loaded erythrocytes $(2.57 \pm 0.27 \mathrm{mM})$, macrophages were extensively washed and then infected with $\mathrm{HSV}-1$ or the $\mathrm{TK}^{-} \Delta 305$ strain. The results obtained (Fig. 3) indicated that the $A C V p_{2} A C V$-loaded RBCs were able to reduce HSV-1 replication in macrophages by $64.6 \%$ (mean of five different experiments, ranging from $40 \%$ to $91 \%$ ). The same treatment was active, although to a lesser extent, against the $\mathrm{TK}^{-}$strain. In fact, in two different experiments each performed in duplicate, the virus titre was reduced by $22.6 \%$ and $40 \%$, respectively. However, it should be noted that the HSV-1 $\mathrm{TK}^{-}$strain used in these preliminary experiments was a deletion clone (A305) with a lower replication rate compared with the parental strain and with clinical $\mathrm{TK}^{-}$isolates, thus these results could not be considered representative of all $\mathrm{TK}^{-}$strains.

As a positive control, infected macrophages were treated for the same time (overnight) with $0.1 \mu \mathrm{M} \mathrm{ACV}$. The results (Fig. 3) indicate that ACV inhibited the replication of HSV by ca. $65 \%$ but was completely ineffective against the HSV TK${ }^{-}$ $\Delta 305$ strain. 


\section{Discussion}

Compounds used for the treatment of HSV disease are nucleoside, nucleotide and pyrophosphate analogues that act as inhibitors of viral DNA polymerase; of these, $\mathrm{ACV}$ is the drug of choice for the treatment of mucosal, cutaneous and systemic HSV-1 and HSV-2 infections. However, once the infection is established, HSV persists in the host for life and current therapy may at best reduce symptoms but is unable to cure and resolve the infection. The long-term treatment and extensive use of ACV has lead to the emergence of resistant viral strains and can also cause various side effects, including hepatitis, renal toxicity and anaphylaxis. Another limitation of $A C V$ in the treatment of herpetic infection is its limited solubility in water (ca. $0.2 \%$ at $25{ }^{\circ} \mathrm{C}$ ) and limited oral bioavailability (15-20\%) [9]. To counteract these problems, several acyclic nucleosides have been developed [10]. Among these, ganciclovir has shown a higher solubility $\left(4.3 \mathrm{mg} / \mathrm{mL}\right.$ in water at $\left.25^{\circ} \mathrm{C}, \mathrm{pH} 7\right)$ but also a higher toxicity compared with ACV. Valaciclovir, the L-valyl ester of ACV, has displayed a higher oral bioavailability (solubility in water $174 \mathrm{mg} / \mathrm{mL}$ ) in comparison with ACV but with no increase in efficacy. Penciclovir was similarly effective and with a prolonged half-life of its activity, but with a lower level of oral absorption than ACV. Better bioavailability (solubility in water at $25^{\circ} \mathrm{C}>25 \% \mathrm{w} / \mathrm{v}$ ) was obtained with famciclovir, the prodrug of penciclovir. Other drugs selected for the treatment of HSV infection are cidofovir and Foscavir ${ }^{\circledR}$, drugs that do not need the TK to be activated, and are indicated as a second-choice drug for the treatment of ACV-resistant HSV lesions, as well as also idoxuridine, trifluridine and brivudin [4]. Alternative drugs to nucleoside analogues for the inhibition of HSV-1 reported in the last decade are oligonucleotide derivatives [11], helicase-primase inhibitors [12] and non-nucleoside polymerase inhibitors [13]. 
However, considering the high selectivity and efficacy of ACV in the treatment of herpetic infection, it is convenient to develop prodrugs of ACV having a higher solubility and bioavailability. For this reason, we have synthesised and evaluated the antiviral activity of a prodrug of $A C V$, namely $A C V p_{2} A C V$. Here we report that the new homodimer is more soluble, which is likely to result in a significant increase in bioavailability. Mole per mole, its efficacy is approximately twice that of ACV and, at the concentration effective against HSV-1, it is non-toxic in cells. This represents very interesting data when considering the selective index of this new compound. In fact, whereas the lack of effect of ACV on DNA synthesis was expected since, like other nucleoside analogues, ACV cannot be converted efficiently into ACV-TP in uninfected cells because of the absence of viral TK, it was necessary to investigate the toxicity of $A C V p_{2} A C V$ since the dimer, once metabolised to ACV-MP, is further converted into ACV or into ACV-TP by cellular kinases and the triphosphate form could interact with cellular DNA synthesis. $A C V p_{2} A C V$ also acts as an efficient antiviral prodrug in macrophages, a cell type known to play a critical role in the pathogenesis of HSV-1 infection. Indeed, macrophages represent an important cellular defence against in vivo HSV-1 infection, but at the same time can be infected by HSV-1 and become a natural reservoir for latent HSV-1 infection in various tissues. In this study, $A C V p_{2} A C V$ was selectively targeted to cells by means a drugtargeting system previously developed by Magnani et al. [7] and successfully used for the delivery of several drugs and nucleotide dimers as prodrugs, such as $A Z T p_{2} A Z T, A Z T p_{2} A C V$ and Bis-PMEA [14], to macrophages.

Extensive use of ACV in clinical therapy has led to the emergence of resistant HSV strains, mainly in immunodeficient patients (ca. 5\%). In this case, the resistant viral 
isolates generate low levels of TK that appear to be insufficient to activate ACV but are high enough to support pathogenesis, particularly in immunocompromised patients [15]. Thus, the protection obtained in macrophages with $A C V p_{2} A C V$ against the $\mathrm{TK}^{-}$strain is very encouraging, although further study on $\mathrm{TK}^{-}$strains isolated from clinical samples are needed to achieve conclusive information on the potency of $A C V p_{2} A C V$ on ACV-resistant HSV-1 strains.

In conclusion, $\mathrm{ACV} \mathrm{p}_{2} \mathrm{ACV}$ acts as an effective antiviral prodrug against $\mathrm{HSV}-1$ both directly administered to Vero cells or following selective targeting to macrophages. The new homodimer presents several advantages compared with $\mathrm{ACV}$, first because of its higher solubility (and bioavailability), and further because its efficacy is approximately double and it is partially active against $\mathrm{HSV}-1 \mathrm{TK}^{-}$strains as well.

Funding: This work was supported by the University of Urbino 'Carlo Bo', Urbino, Italy.

Competing interests: None declared.

Ethical approval: Not required. 


\section{References}

[1] Whitley RJ, Roizman B. Herpes simplex virus infections. Lancet 2001;357:15138.

[2] Stanberry LR, Jorgensen DM, Nahmias AJ. Herpes simplex viruses 1 and 2. In: Evans AS, Kaslow R, editors. Viral infections of humans: epidemiology and control. 4th ed. New York, NY: Plenum Publishers; 1997. p. 419-54.

[3] Whitley RJ. Herpes simplex virus. In: Fields BN, Knipe DM, Howley PM, editors. Virology. Philadelphia, PA: Lippincott-Raven Publishers; 1996. p. 2297-342.

[4] De Clercq E. Antiviral drugs in clinical use. J Clin Virol 2004;30:115-33.

[5] Mertz GJ. Herpes virus simplex. In: Galasso GJ, Whitley RJ, Merigan TC, editors. Antiviral agents and viral disease of man. New York, NY: Raven Press; 1990. p. 265-300.

[6] Rossi L, Brandi G, Schiavano GF, Balestra E, Millo E, Scarfi S, et al. Macrophage protection against human immunodeficiency virus or herpes simplex virus by red blood cell-mediated delivery of a heterodinucleotide of azidothymidine and acyclovir. AIDS Res Hum Retroviruses 1998;14:435-44.

[7] Magnani M, Rossi L, Brandi G, Schiavano GF, Montroni M, Piedimonte G. Targeting antiretroviral nucleoside analogues in phosphorylated form to macrophages: in vitro and in vivo studies. Proc Natl Acad Sci USA 1992;89:647781.

[8] Brandi G, Schiavano GF, Balestra E, Tavazzi B, Perno C-F, Magnani M. The potency of acyclovir can be markedly different in different cell types. Life Sci 2001;69:1285-90.

[9] Weller S, Blumm M, Doucette M, Burnette T, Cederberg DM, De Miranda P, el al. Pharmacokinetics of the acyclovir pro-drug valaciclovir after escalating single, and 
multiple-dose administration to normal volunteers. Clin Pharmacol Ther 1993;54:595-605.

[10] De Clercq E, Field HJ. Antiviral prodrugs-the development of successful prodrug strategies for antiviral chemotherapy. Br J Pharmacol 2006;147:1-11.

[11] Van Aerschot AV. Oligonucleotides as antivirals: dream or realistic perspective? Antiviral Res 2006;71:307-16.

[12] Kleymann G. Agents and strategies in development for improved management of herpes simplex virus infection and disease. Expert Opin Investig Drugs 2005;14:135-61.

[13] Firestine SM. Recent advances in herpes simplex virus antiviral therapies. Expert Opin Ther Pat 2004;14:1139-51.

[14] Rossi L, Serafini S, Franchetti P, Cappellacci L, Fraternale A, Casabianca A, et al. Targeting nucleoside dimers containing antiviral nucleosides. Curr Med Chem Anti-Infect Agents 2005;4:37-54.

[15] Griffiths A, Coen DM. An unusual internal ribosome entry site in the herpes simplex virus thymidine kinase gene. Proc Natl Acad Sci USA 2005;102:9667-72. 
Fig. 1. Metabolism of $A C V p_{2} A C V$ in human plasma. $A C V p_{2} A C V(0.08 \mu \mathrm{mol} / \mathrm{mL}$ of plasma) was incubated for $5 \mathrm{~h}$ at $37^{\circ} \mathrm{C}$. At the indicated time, perchloric acid extracts were prepared and analysed by high-performance liquid chromatography. ACV-MP, aciclovir monophosphate; ACV, aciclovir.

Fig. 2. Inhibition of herpes simplex virus type 1 (HSV-1) replication by aciclovir (ACV) and its homodimer $A C V p_{2} A C V$ in Vero cells. Cells were infected with 3 plaqueforming units/cell in the presence or absence of different concentrations of drugs. Viral production was assayed 2 days post infection by plaque assay in Vero cells. Data are from a single experiment representative of three.

Fig. 3. Inhibition of herpes simplex virus type 1 (HSV-1) replication by aciclovir (ACV) and its homodimer ACVp2ACV in human macrophages. Cells were treated overnight and then infected with 3 plaque-forming units (PFU)/cell of HSV-1 or $10 \mathrm{PFU} / \mathrm{cell}$ of $\mathrm{HSV}-1 \mathrm{TK}^{-} \Delta 305$. Viral production was evaluated as in Fig. 2. Data are from two to five experiments, each performed in duplicate. RBC, red blood cells (erythrocytes). 


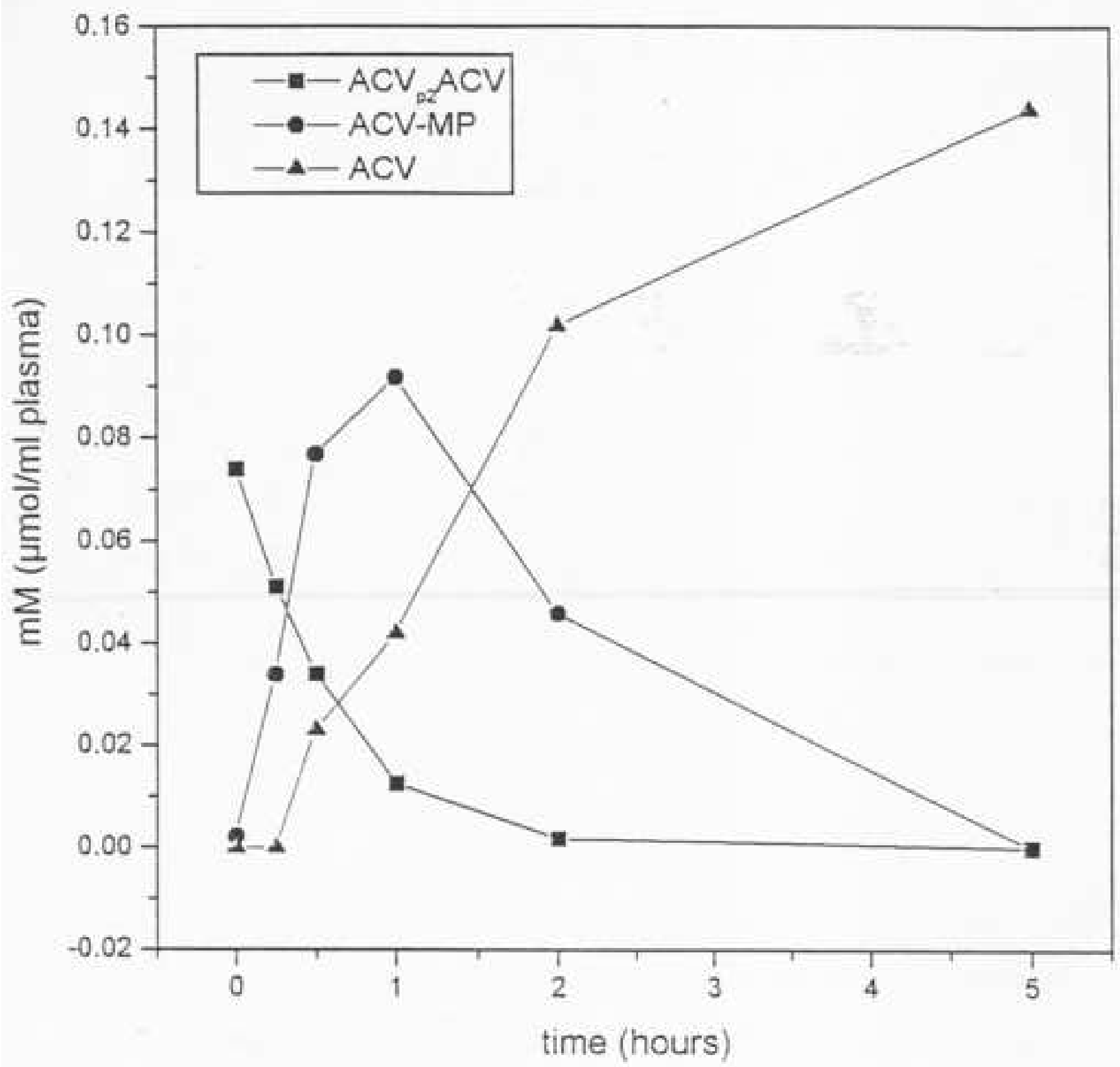

rage 16 or 18 


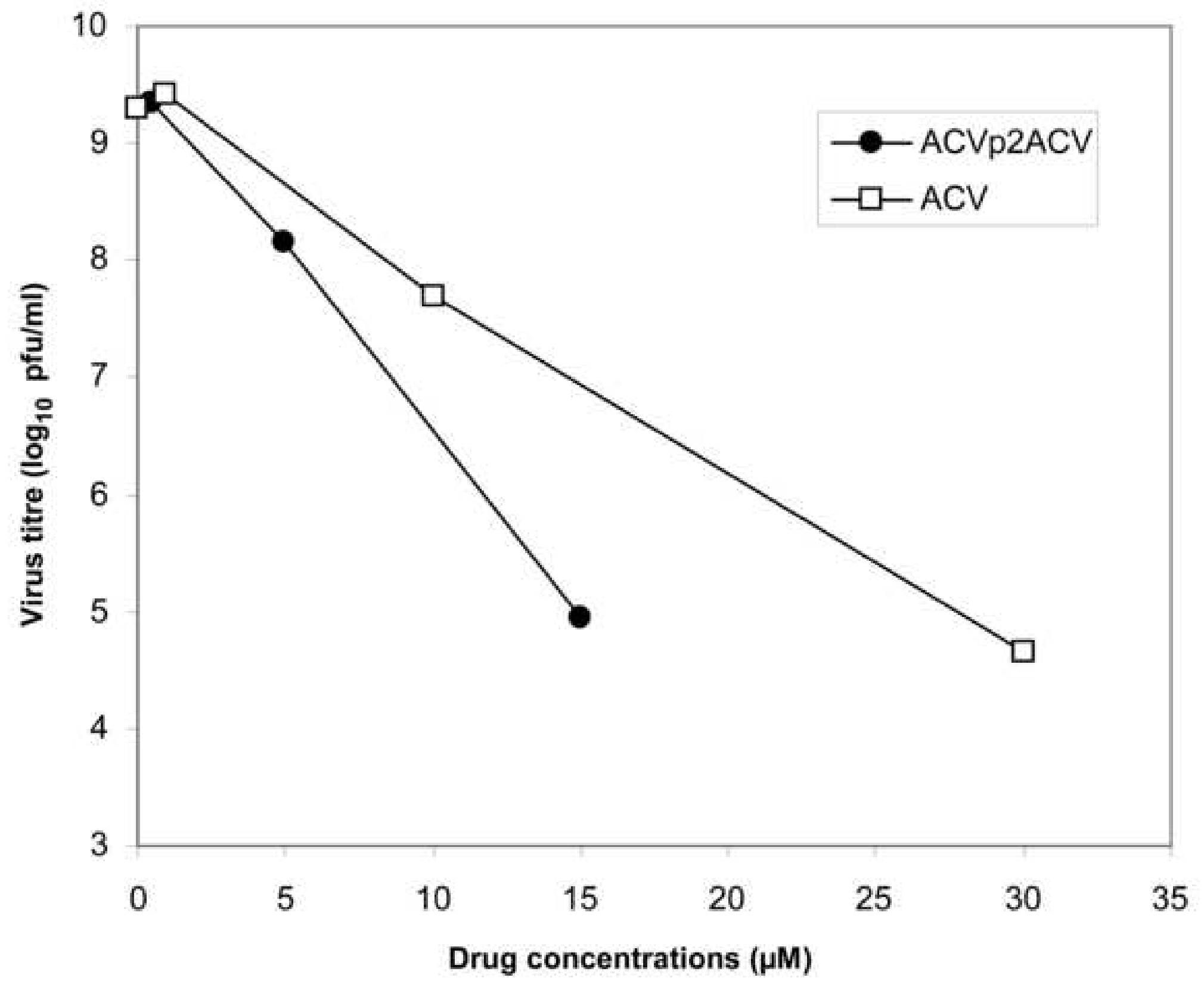

Page 17 of 18 


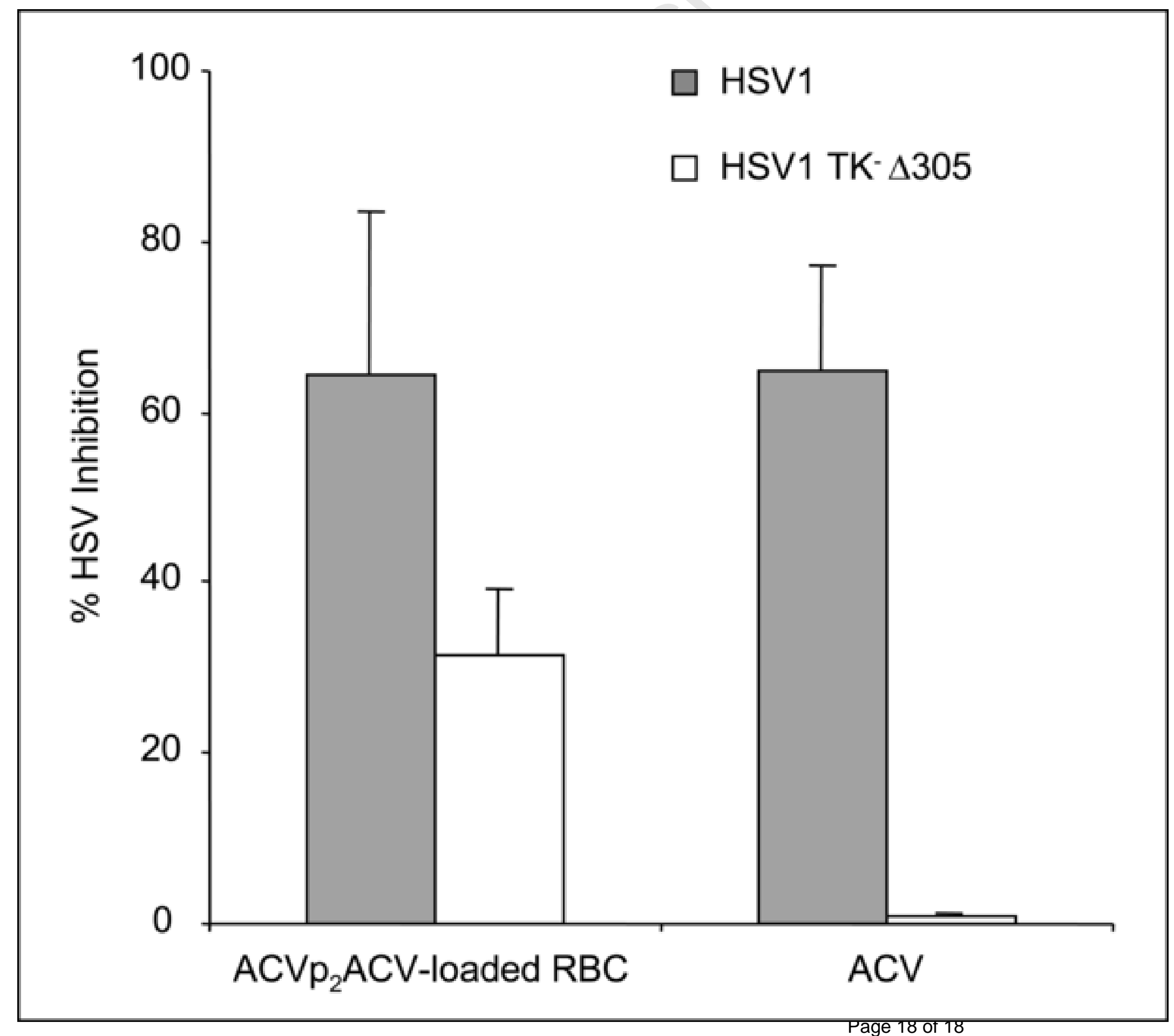

